\title{
Virtual Workspaces for Enhancing Collaborative Work in EFL Learning: A Case Study in Higher Education
}

\author{
https://doi.org/10.3991/ijet.v17i02.25937 \\ Luz Castillo-Cuesta( $\left.{ }^{(}\right)$, Cesar Ochoa-Cueva, Paola Cabrera-Solano \\ Universidad Técnica Particular de Loja, Loja, Ecuador \\ lmcastillox@utpl.edu.ec
}

\begin{abstract}
The purpose of this study was to determine students' perceptions towards the use of virtual workspaces for enhancing collaborative work in higher education. The participants were 122 (72 graduate and 50 postgraduate) Teaching English as a Foreign Language (TEFL) students who were enrolled in different courses at a private university in Ecuador. The students' proficiency levels varied from B1 to $\mathrm{C} 1$ according to the Common European Framework of Reference for Languages (CEFR). A mixed-method approach was used comprising qualitative and quantitative methods; thus, a diagnostic questionnaire, a perceptions questionnaire, a semi-structured interview, and observation checklists were administered as instruments. This research involved an online instructional process in which teachers implemented virtual workspaces using Jamboard as a tool to design collaborative activities. The results evidenced that the use of virtual workspaces helped students develop their collaborative skills and promoted their open-mindedness. Also, virtual workspaces allow teachers to build positive e-learning environments in which students can discuss topics from different perspectives and show respect for each other's ideas.
\end{abstract}

Keywords—-virtual workspaces, EFL learning, Jamboard, collaborative work

\section{Introduction}

The Covid-19 pandemic has provoked unprecedented effects in all educational systems around the world [1]. An important implication caused by this global crisis has been the teachers' and students' need to move to online modes of instruction in order to ensure continuity of teaching and learning [2]. However, in this contingency plan, EFL instructors have encountered significant challenges in carrying out online teaching during the pandemic. Some of these issues deal with lack of Information and Communication Technologies (ICT) training, unstable internet connection, or students' low literacy in the target language [3]. For this reason, [4] suggests that several actions should be implemented to reduce the obstacles faced by EFL teachers. Among these solutions, the use of technology is an essential action that all educational institutions should incorporate, especially in higher education.

In this regard, [5] claim that technology has become an integral part of the learning experience and a significant issue for teachers. [6] state, "The era of technology and 
information uncovers new challenges every day, which calls for expanding novel approaches to achieve efficient teaching and instruction" (p.96). Moreover, according to [7], teaching methods have been changing due to technology. Furthermore, teachers should use technology effectively to support the curriculum so that students can increase its use to learn language skills [8]. In this regard, [9] asserts that teachers should encourage students to find suitable activities through the use of technology to be successful in language learning. It is evident that technology helps instructors to teach in a better way and its use has been even more relevant during critical situations such as the Coronavirus-19 pandemic [10]. Thus, EFL teachers should enhance students' performance by using technology in absence of face-to-face instruction [11].

In this pandemic context, one of the most important benefits of using ICT in EFL teaching is that it offers several opportunities for collaborative work. As [12] acknowledge, technology has made collaborative learning a reality. Certainly, activities and projects can be easily carried out through the use of technological tools, which eliminates barriers such as time, distance, and resources [13]; [14]. EFL teachers can use collaborative technology to coordinate group work, record progress, and give feedback [15]. In this regard, wikis, blogs, social networks, teamwork-based games, and virtual workspaces offer many possibilities for collaboration among EFL learners. Concerning virtual workspaces, [16] affirms that they are places where learners can meet to support and encourage each other. One of these workspaces is Jamboard, which is a Google product that is used to strengthen virtual collaboration. Jamboard allows students to work together on projects, brainstorm ideas, and design concept maps; in fact, this tool fosters learners' collaboration and participation in an innovative way [17].

Several studies have focused on the use of virtual workspaces to promote collaborative work in EFL education. [18] Analyzed students' interactions in Slack workspaces and demonstrated the strength of social interaction despite physical distancing. [19] Researched teaching strategies during the Covid-19 pandemic. Their findings evidenced that teachers used Telegram, WhatsApp, Google Classroom, and Zoom to engage students in the learning process while Quizizz, Padlet, and Kahoot were used for online assessment. Furthermore, [20] emphasized the use of social media, WhatsApp, Google Classroom, and Zoom as the most common tools to promote interaction and collaborative work during the pandemic. Nevertheless, many teachers in Ecuador have not explored all the possibilities and benefits that virtual workspaces offer, especially during prolonged periods of lockdown. Therefore, this research constitutes a contribution to shed light on the use of virtual workspaces to promote collaborative work in EFL learning. Thus, this study attempts to answer the following research questions:

- What are students' perceptions of the use of virtual workspaces for enhancing virtual collaborative work in the EFL context?

- What is the influence of the use of virtual workspaces to enhance EFL students' collaborative work? 


\section{Literature review}

\subsection{Remote education during the Covid-19 pandemic}

In terms of [21], as a result of crisis events such as the current pandemic, the use of emergency remote teaching (ERT) is a temporary change of instructional delivery to an alternate type. They also claim that ERT includes the use of total remote teaching solutions for education which, in other cases, would be delivered face-to-face and that will return to such a format once the crisis has ended. Therefore, the main purpose under these circumstances is not to re-create a strong educational environment but rather to deliver temporary access to education in a way that is quick to be implemented and reliably accessible in an emergency.

In this same line of thought, [22] explain that emergency remote teaching and online distance education are not similar. On one hand, online distance education deals with interactions between different participants and through diverse channels that allow students to be more engaged in the learning process. On the other hand, what is currently happening as a consequence of the Covid-19 pandemic is referred to as emergency remote teaching, which should be seen as a temporary solution to an immediate problem. Although it is real that temporary solutions benefit from the practices of online distance education, it is not fair to identify online distance education and emergency remote teaching as the same.

Furthermore, [23] claims that many universities around the world have emergently shifted to remote teaching due to the Covid-19 pandemic. This shift from face-to-face education to remote teaching requires us to rely on synchronous attendance which proves to be challenging due to technology, connectivity, availability, and time zones constraints. On the contrary, in the case of online courses, they are designed based on many standards to ensure optimal learning; thus, what is acceptable as emergency remote teaching may not be appropriate for an online course. In this regard, instead of trying to reproduce face-to-face activities using technology, it would be necessary to create quality online courses by engaging learners with the content, fostering teamwork, and building community.

\section{2 $\quad$ EFL learning and teaching}

The coronavirus pandemic has had a big impact on almost all aspects of human life, including the process of EFL teaching around the world [24]. For this reason, when the pandemic began, online learning was the only alternative for students and teachers to continue with the learning process from home; however, during this process, aspects such as lack of preparation and planning affected students' performance in this new modality [3]. In this context, when students are part of an online system, they face different challenges, which include some feelings of isolation, lack of selfconfidence, more pressure to increase their self-learning, and independent workload [25]. In fact, [26] asserts that online environments can make students feel excluded, which is an issue that needs to be solved especially by the teacher. 
Based on the aforementioned issues, it is important to remark that the use of highquality online resources offers several possibilities to be adopted in the field of EFL teaching and learning [27]. In fact, the authors suggest that the "Covid-19 pandemic has spurred educational institutions to rapidly adapt in-classroom learning, the online format of educating teacher candidates has prevailed" (p. 592). However, despite all the issues toward using technologies in EFL instruction, the online classroom has a big potential during the pandemic, especially because it can help teachers who belong to different backgrounds to get connected with students and continue the teaching and learning process. Besides, through online classes, many school leaders and teachers had the opportunity to reduce the learning disruption caused by the pandemic [11].

\subsection{ICT for collaborative work in EFL learning}

Technology has revolutionized the pedagogical environment and made collaborative learning a reality [12]. Thus, the use of technology facilitates collaborative learning and permits that people share activities and projects eliminating the barriers of time, distance, and resources [13]. ICT provides new opportunities for learning in an increasingly connected world, in which working collaboratively has become an indispensable skill [28]. Nevertheless, collaboration does not occur naturally in a group; therefore, it is necessary to apply strategies to coordinate individual efforts and monitor the learning process to provide the required conditions for effective collaboration [29]. As [15] acknowledges, ICT as a collaborative technology offers functionalities to coordinate group work, record progress, and give feedback. Certainly, building and sharing constitute transversal objectives for which the use of technology proves to be valuable for developing curricula and for teaching students [28].

In the EFL context, ICT can be used to promote collaborative work in different ways. Wikis, Blogs, social networking services such as Facebook or Twitter, Virtual Worlds, teamwork-based games, and workspaces offer many possibilities for collaboration among EFL learners. Regarding online workspaces, [16] asserts that they are places where learners can meet to support and encourage each other. Jamboard, which is a Google product, can be used to foster virtual collaboration, students can work together on projects, they can also brainstorm ideas about any topic or design concept maps. As [30] acknowledges, Jamboard is a practical, interactive, and functional alternative that permits users to add labels, images, and different backgrounds; also, a teacher can easily share the link with students synchronously and allow them to participate in real-time activities. The use of Jamboard encourages students to learn, collaborate and participate in an innovative way [17].

\subsection{Previous studies}

[18] Investigated a teacher's ongoing efforts to develop and deliver distance learning EFL courses in a higher education context. Synchronous distance courses were developed using a text-messaging application and collaborative text-editing software to establish a communicative learning space. Analysis of the students' interactions in Slack workspaces indicated a variety of interpersonal, open, and cohesive communi- 
cation that signaled psychological closeness in the virtual learning environment. Group discussion sessions revealed that students could feel connected to each other in the synchronous EFL courses, which demonstrated the strength of social interaction despite physical distancing. Major difficulties lay in three areas that include technology, the nature of the task, and some students' task preferences.

[19] Analyzed ESL strategies to teach English at selected secondary schools in Malaysia during the pandemic. A descriptive case study design was used and eight ESL teachers participated voluntarily. Open-ended questions were given to the teachers through WhatsApp to obtain feedback regarding their teaching strategies during the pandemic. The findings evidenced that the ESL teachers used Telegram, WhatsApp, Google Classroom, and Zoom to foster collaboration among students and engage them in the learning process. In addition, teachers used Quizizz, Padlet, and Kahoot for online assessment. Other findings included problems teachers encountered when engaging students through the apps used.

[31] Studied the effectiveness of an online collaborative learning platform with TOEIC English tests as learning content. A total of 48 graduate university students participated in this study. Two experimental groups and a control group were part of this research. A pre-test and a post-test were used from a grammar book to understand the effects of learning style-based grouping collaborative learning on students' English grammar and vocabulary. The main results indicate that students who used the online English collaborative learning approach outperformed those who used the traditional paper-based English collaborative learning approach.

[32] Carried out an action research study whose purpose was to explore the types of interactions that EFL students experience while using a wiki as a supporting tool in a face-to-face course. A pedagogical intervention based on a collaborative online learning interaction was implemented. The data were gathered from 128 participants' posts, which were qualitatively analyzed as a result of the tasks suggested along the course. The findings reveal that class tasks promoted an asynchronous voluntary interaction among participants in which they shared knowledge and experiences while expressing the opinions and points of view that enabled them to actively participate in a face-to-face class.

[20] Conducted a study to investigate the implementation of communicative teaching media in EFL instruction during the pandemic. The participants were 22 female and 2 male English teachers from senior high schools in Indonesia. The study followed a qualitative method in which a literature study approach and a questionnaire were used to obtain data. The main findings revealed that social media dominates the implementation of communicative teaching media in Indonesia. Besides, English teachers frequently used a variety of ICT tools such as WhatsApp, Google Classroom, and Zoom being the most common ones. In fact, the authors found that the simplicity of these tools promoted collaborative and practical work, active teaching, and learning activities during the pandemic since students were required to interact with other students and teachers.

[33] Carried out a study to identify students' opinions on ESL/EFL classes during the pandemic. The research followed a qualitative method and the participants were two classes of EFL/ESL second-year students from a local high school in North Mac- 
edonia. An online questionnaire was administered to ask students' perceptions about the online activities in which they participated during remote learning. The results revealed that students found collaborative activities really engaging and exciting since they had the opportunity to use a variety of apps and online activities such as Kahoot, Nearpod, Google Jamboard, AnswerGarden, Slido, among others. In fact, these activities increased their motivation and interest because students perceived that they enjoyed online ESL/EFL classes, sometimes even more than on-site lessons.

\section{$3 \quad$ Method}

\subsection{Setting and participants}

This study was carried out at a private university in Ecuador; a total of 122 students, 72 graduate and 50 postgraduate TEFL learners participated in this research. The participants' ages ranged between 20 and 50 years old. The graduate students' proficiency level varied from B1 to B2 while the postgraduate participants' level was C1 according to the Common European Framework of Reference for Languages [34]. These levels correspond to the requirements established by the university at both distance and on-site study modalities. The participants enrolled in both study programs worked by means of emergency remote learning because of the Covid-19 pandemic.

\subsection{Instruments}

- A diagnostic questionnaire was administered to determine the students' previous experience in using workspaces for collaborative activities. It included a total of 12 items (open and closed-ended questions).

- An observation checklist was used to register 8 aspects related to students' collaborative work. These aspects were observed and rated through a Likert scale that ranged from very low to very high.

- A students' perceptions questionnaire was applied to gather information about their experience when using Jamboard for collaborative work. It comprised 10 Likertscale items which included three levels (agreement, uncertainty, and disagreement).

- A semi-structured interview (6 questions) was administered to develop an in-depth description of students' experience during the implementation of this study.

\subsection{Procedure}

In this study, a mixed-method approach was used which comprised qualitative and quantitative methods. According to [35], the basic assumption of this approach is that the combination of qualitative and quantitative methods permits a more complete understanding of a research problem than either method alone. This research was conducted during a five-month period in which graduate and postgraduate students 
worked remotely through Zoom meetings and the virtual Canvas platform due to the Covid-19 pandemic.

At the initial stage, all the participants responded to a diagnostic questionnaire which was administered through Google Forms. The results of this survey allowed researchers to diagnose students' previous experience in using workspaces for collaborative work, which was a useful starting point to plan the instruction process.

During the implementation process, teachers designed activities using Jamboard such as brainstorming, summarizing ideas, constructing concept maps, providing group feedback, and discussing specific topics related to the contents of the study programs. Such activities were applied twice a month during the instruction process, which required students to previously read certain topics as a major source of input. Pairwork and group work activities were used for the students to work collaboratively and their presentations were shown in Jamboard spaces, as it can be seen in Figure 1.

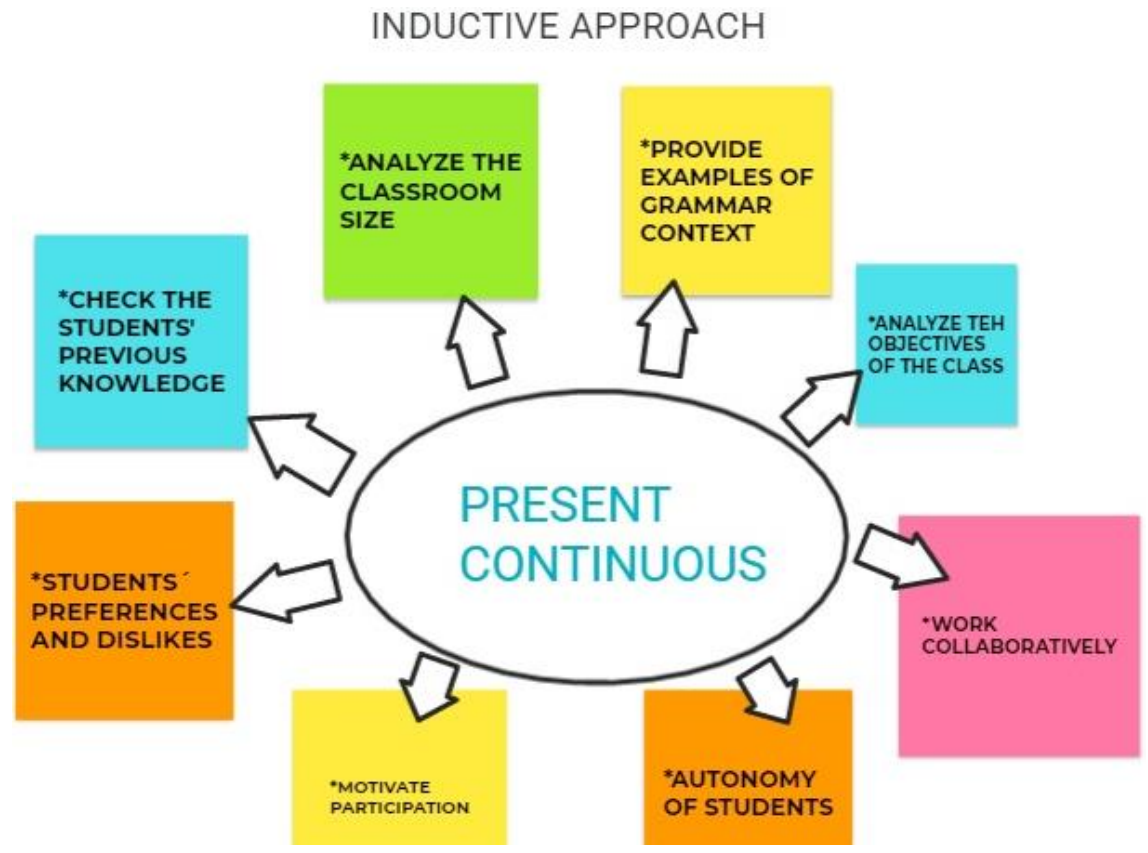

Fig. 1. Jamboard activity

In this stage, observation checklists were used to gather information about students' responsibility, engagement, peer feedback, active work, motivation, commitment, creativity, and confidence. In addition, teachers offered permanent feedback to help students face their weaknesses.

After the instruction process, a perceptions questionnaire was administered to determine students' experience when using Jamboard for collaborative work. Furthermore, a semi-structured interview was delivered to a group of 20 students (10 graduate and 10 postgraduate learners) through Zoom meetings, which facilitated this process. 


\section{$4 \quad$ Results and discussion}

Before the instruction process, a diagnostic survey was administered to identify students' previous experience in using virtual workspaces for collaborative activities. The results of this survey revealed that $72 \%$ of the students indicated that their skills for collaborative work were excellent and very good; in addition, $76.5 \%$ perceived their skills for using ICT tools as very good. This means that they were very acquainted with the use of virtual platforms for collaborative work. Moreover, $75 \%$ of the students affirmed that they had used platforms such as Canvas, Zoom, Moodle, Microsoft Teams, among others for collaborative activities in previous courses. Furthermore, they mentioned that they would like to foster communication, organization, open-mindedness, and discussion through collaborative work especially during remote teaching and learning. In order to successfully implement collaborative work, the participants affirmed that teachers should use creative, productive, interesting, and engaging tools because they have experienced isolation and lack of interaction with their peers.

To meet the learners' needs that were identified in the diagnostic survey, collaborative activities using Jamboard were designed and implemented. These activities, which were planned according to the course competencies, involved reading, selfreflection, discussion, organization, communication, and evaluation.

Regarding students' perceptions, Table 1 shows the participants' level of agreement with respect to the use of Jamboard as a virtual workspace for enhancing collaborative work.

Table 1. Students' perceptions of the use of virtual workspaces

\begin{tabular}{|l|l|c|c|c|}
\hline \multicolumn{1}{|c|}{ Statements } & \multicolumn{1}{|c|}{ Level of agreement } \\
\cline { 3 - 5 } & \multicolumn{1}{|c|}{$\begin{array}{l}\text { Agreement } \\
\text { The use of Workstainty }\end{array}$} & Disagreement \\
\hline cies in this course. & $96.72 \%$ & $1.64 \%$ & $1.64 \%$ \\
\hline 2 & $\begin{array}{l}\text { Jamboard was an interesting tool that fostered my open- } \\
\text { mindedness toward other partners' contributions. }\end{array}$ & $92.62 \%$ & $3.28 \%$ & $4.10 \%$ \\
\hline 3 & Workspaces promoted my communication skills. & $90.98 \%$ & $4.92 \%$ & $4.10 \%$ \\
\hline 4 & $\begin{array}{l}\text { Workspaces fostered my adaptability to work with my partners } \\
\text { and teacher in a creative way. }\end{array}$ & $90.16 \%$ & $4.92 \%$ & $4.92 \%$ \\
\hline 5 & $\begin{array}{l}\text { Jamboard fostered my collaborative skills to contribute to my } \\
\text { group and provide feedback. }\end{array}$ & $92.62 \%$ & $2.50 \%$ & $4.88 \%$ \\
\hline 6 & Workspaces stimulated my long-term thinking. & $85.25 \%$ & $8.19 \%$ & $6.56 \%$ \\
\hline 7 & $\begin{array}{l}\text { The activities developed by means of the Jamboard tool were } \\
\text { rewarding. }\end{array}$ & $90.16 \%$ & $5.74 \%$ & $4.10 \%$ \\
\hline 8 & Jamboard was an innovative and engaging tool. & $86.89 \%$ & $8.19 \%$ & $4.92 \%$ \\
\hline 9 & $\begin{array}{l}\text { The use of Jamboard increased my interest and motivation to } \\
\text { participate in the course activities. }\end{array}$ & $89.34 \%$ & $6.56 \%$ & $4.10 \%$ \\
\hline 10 & $\begin{array}{l}\text { Workspaces allowed me to improve my technological compe- } \\
\text { tencies for academic purposes. }\end{array}$ & $92.62 \%$ & $4.88 \%$ & $2.50 \%$ \\
\hline
\end{tabular}


As for the influence of the use of Jamboard as a virtual workspace for collaborative work, the observation checklist (see Table 2) presents the most significant results that were relevant during the implementation.

Table 2. Observation checklist

\begin{tabular}{|l|l|c|c|c|c|c|}
\hline $\mathbf{N}^{\circ}$ & \multicolumn{1}{|c|}{ Aspects } & Very low & Low & Moderate & High & Very high \\
\hline 1 & $\begin{array}{l}\text { Students were responsible when participating in col- } \\
\text { laborative activities. }\end{array}$ & & & & $\mathrm{x}$ \\
\hline 2 & $\begin{array}{l}\text { Students were engaged in the activities their teacher } \\
\text { proposed. }\end{array}$ & & & $\mathrm{x}$ & $\mathrm{x}$ \\
\hline 3 & $\begin{array}{l}\text { Students offered and received feedback from their } \\
\text { peers. }\end{array}$ & & & $\mathrm{x}$ & \\
\hline 4 & $\begin{array}{l}\text { Students actively participated in the collaborative } \\
\text { activities. }\end{array}$ & & & $\mathrm{x}$ & $\mathrm{x}$ \\
\hline 5 & $\begin{array}{l}\text { Students were creative in designing and presenting } \\
\text { collaborative projects. }\end{array}$ & & & $\mathrm{x}$ \\
\hline 6 & $\begin{array}{l}\text { Students were confident when working in groups and } \\
\text { sharing products in Jamboard. }\end{array}$ & & & $\mathrm{x}$ \\
\hline 7 & $\begin{array}{l}\text { Students were motivated when participating in collabo- } \\
\text { rative activities using Jamboard. }\end{array}$ & & & & \\
\hline 8 & $\begin{array}{l}\text { Students were committed to participating in collabora- } \\
\text { tive activities using Jamboard. }\end{array}$ & & & & \\
\hline
\end{tabular}

Regarding the use of Jamboard as a virtual workspace, most of the students $(96.72$ $\%$ ) agreed that it was very useful to develop their course competencies, $1.64 \%$ did not express agreement or disagreement, and $1.64 \%$ did not agree with this statement. These results are related to the students' engagement and active participation that was evident during collaborative activities, which was also reported in the observation. Furthermore, most of the students in the interview affirmed that they felt encouraged to participate because their teacher offered clear instructions and created a positive environment that allowed equal participation for everyone. As [36] suggests, the use of technological tools allows teachers to implement more student-centered activities in which they have an active learning role.

With respect to the participants' perceptions of Jamboard as a tool to promote open-mindedness, the majority of students $(92.62 \%)$ agreed that the use of this tool fostered their willingness to listen to their peers and decide how to present the team contributions in Jamboard. These findings are consistent with the research conducted by [18] in which students' interactions in Slack workspaces were analyzed revealing that they were willing to collaborate with their partners despite physical distancing. Participants also had a positive perception regarding the use of workspaces to foster their communication skills. Thus, most of them (90.98\%) agreed with this aspect. These results might be linked to students' confidence, which was observed when they had the opportunity to work in groups and share their products in Jamboard. During the interview, students acknowledged that they felt confident when using Jamboard because it is an easy-to-use tool that helped them trust their capabilities. In addition, they could discuss topics from different perspectives and the group members showed 
respect for each other's ideas. These findings are aligned with those obtained by [37] which revealed that including technology in EFL teaching has a significant impact on the learners' oral skills development. Certainly, the use of ICTs offers teachers the possibility to create learning environments in which students can communicate effectively [38].

As for adaptability to work collaboratively and creatively, $90.16 \%$ of the students expressed agreement because they considered that the use of workspaces facilitated group work and allowed them to present their tasks in an original way. During the observation, one of the most important aspects reported was creativity, which was especially evident when students designed and presented their collaborative projects. In the interview, students emphasized that the activities using Jamboard challenged them to present their group projects in a non-traditional way; thus, they could include graphic organizers, pictures, and other visual elements that they decided on as a team. In this respect, [17] acknowledge that workspaces, like Jamboard, encourage students to learn, collaborate and participate in an innovative way.

Concerning students' perceptions about Jamboard as a tool that can help learners foster their collaborative skills, $92.62 \%$ of them were in accordance with this aspect. In fact, in the observation, the students were actually committed to participate in all the collaborative activities that were implemented through this tool. These results are aligned with the ones obtained in the interview, in which students expressed that they felt committed to practicing the target language because they learned new things in a non-traditional way. They also liked to work in groups and receive valuable feedback from their teachers and partners. These findings corroborate those of [39] who found out that collaborative tools positively influenced students' perceptions towards English language learning because they shared information, felt self-confident, and learned a lot from their peers.

When students were asked if virtual workspaces stimulated their long-term thinking, a high percentage of learners $(93,44 \%)$ agreed with this aspect, while $8.19 \%$ seemed to be uncertain about this issue. As for the observation, even though longterm thinking was not an evident aspect in the learning process, most of the students were highly engaged in all the activities proposed by their teacher during the intervention, which really influences students' development of this mental process. In addition, students in the interview asserted that Jamboard was an accessible tool that allowed them to explore many options according to their real learning needs. This was a fundamental aspect to stimulate their long-term thinking during remote learning sessions. According to [40], collaborative tools encourage students' participation and give them social, interactive, and multimodal learning opportunities; for this reason, tools such as Jamboard are efficient and useful to enhance learning English even beyond the classroom. In fact, these tools give teachers the opportunity to plan several activities based on students' learning needs, which stimulates them to learn the target language.

In relation to students' perceptions about the different types of activities that they carried out on the Jamboard tool, $90.16 \%$ of them asserted that they were rewarding, which means that learners were satisfied with the use of this tool and also with the topics discussed. This result is reflected in the learners' performance that was ob- 
served during the intervention in which students seemed engaged with the activities and tasks since they were really gratifying. Indeed, according to the interview, participants showed a positive perception regarding the collaborative tasks planned by their teachers since Jamboard offers different alternatives that were very useful to enrich their knowledge. These results are similar to the ones obtained by [41], who found out that when students are exposed to collaborative tools such as Jamboard, their satisfaction increases and they want to continue using this type of e-learning tools because of their ease of use and playfulness.

Students were also asked whether Jamboard was innovative and engaging and in this regard, they agreed $(86.89 \%)$ that this tool, which includes novel features, helped them to design the activities in class. In the interview, students manifested that Jamboard allowed them to include not only text but visual elements. Thus, participants had more freedom to express their originality to present their tasks, which is very rewarding as students can use Jamboard to innovate their EFL classes. These results are aligned with the findings of the study by [17] in which Jamboard encouraged learners to collaborate and participate in an innovative way.

In addition, participants $(89.34 \%)$ agreed that Jamboard increased their interest and motivation to engage in the activities of the course. During the observations, it was seen that the learners were motivated when they took part in activities using Jamboard. Furthermore, in the students' interview, participants explained that Jamboard, on one hand, motivated them to know their classmates' perspectives about the topics discussed in the class; and on the other hand, by means of this tool, they were able to share files, data, images, links, and mind maps to enrich the classes and make them more interesting. These findings are supported by [33] whose study revealed that students' motivation and interest increased when using Jamboard because they really enjoyed online ESL/EFL classes.

In the last statement, $92.62 \%$ of the students perceived that workspaces allowed them to improve their technological competencies for academic purposes. In fact, participants were able to add technological features to their presentations such as charts, labels, backgrounds, among others when participating in the collaborative activities assigned by the teachers. In this regard, [42] state that there are positive attitudes when students apply technology and it should be more frequently used in teaching and learning the English language.

\section{Conclusions}

The use of virtual workspaces fosters TEFL students' linguistic competencies of the target language and collaborative work. Students perceived that the instructions offered were clear and they could work in a positive learning environment that allowed equal participation for everyone. In addition, the effective use of virtual workspaces gives pre and in-service teachers the opportunity to enhance their teaching skills due to the variety of possibilities that they offer in EFL instruction.

Jamboard as a virtual workspace is an easy-to-use tool that allows teachers to design activities that foster students' confidence, open-mindedness, and interaction. In 
addition, this tool permits students to develop their creativity and dynamically work on collaborative projects since they could discuss topics from different perspectives and the group members showed respect for each other's ideas.

The implementation of activities in virtual workspaces offers multimodal learning opportunities that can stimulate EFL students' long-term thinking based on learners' real needs. This implies that the implementation of innovative activities in Jamboard can be a useful strategy to boost graduate and postgraduate learners' skills even beyond the classroom.

Collaborative online activities in Jamboard are perceived by EFL students as rewarding because this tool offers a variety of alternatives that can enrich their knowledge. Certainly, it is essential to create a good atmosphere in virtual settings since it can promote active and collaborative learning especially during the Covid-19 pandemic in which EFL teachers should promote interaction among students.

Virtual workspaces are valuable and motivating learning environments that help students improve their technological competencies in the academic field and increase their interest in learning. By means of the Jamboard features that learners can include in presentations, collaborative activities become more effective because they have more freedom to depict originality when delivering their projects in class.

The implementation of activities using virtual workspaces demands careful planning which must be aligned to the course competencies and students' academic requirements so that the learning outcomes can be successfully achieved. EFL teachers should provide permanent feedback along with the application of activities using Jamboard as a virtual workspace. Further research should be conducted to explore the way in which Jamboard can be used in assignments or other activities that are not supervised by teachers.

\section{Acknowledgment}

We would like to thank the Universidad Técnica Particular de Loja authorities and the EFL Learning, Teaching and Technology Research Group for promoting and supporting this research.

\section{$7 \quad$ References}

[1] G. Marinoni, H. Van't Land, and T. Jensen, "The impact of Covid-19 on higher education around the world," IAU Glob. Surv. Rep., 2020. https://doi.org/10.18326/rgt.v13i1.49-76

[2] J. Allen, L. Rowan, and P. Singh, "Teaching and teacher education in the time of COVID19.” Taylor \& Francis, 2020. https://doi.org/10.1080/1359866X.2020.1752051

[3] A. E. P. Atmojo and A. Nugroho, "EFL classes must go online! Teaching activities and challenges during COVID-19 pandemic in Indonesia," Regist. J., vol. 13, no. 1, pp. 49-76, 2020. https://doi.org/10.18326/rgt.v13i1.49-76

[4] L. Efriana, "Problems of Online Learning during Covid-19 Pandemic in EFL Classroom and the Solution," JELITA, pp. 38-47, 2021.

[5] M. Eady and L. Lockyer, "Tools for learning: Technology and teaching," Learn. to teach Prim. Sch., vol. 71, 2013. https://ro.uow.edu.au/asdpapers/403 
Paper-Virtual Workspaces for Enhancing Collaborative Work in EFL Learning: A Case Study in...

[6] T. Heydarnejad, A. H. Fatemi, and B. Ghonsooly, "The Relationship between Critical Thinking, Self-regulation, and Teaching Style Preferences among EFL Teachers: A Path Analysis Approach," J. Lang. Educ., no. 1, pp. 98-110, 2021. https://doi.org/10. $\underline{17323 / \mathrm{jle} \text {.2021.11103 }}$

[7] A. P. Gilakjani, "A review of the literature on the integration of technology into the learning and teaching of English language skills," Int. J. English Linguist., vol. 7, no. 5, pp. 95-106, 2017. https://doi.org/10.5539/ijel.v7n5p95

[8] K. C. Costley, "The Positive Effects of Technology on Teaching and Student Learning.," Online Submiss., 2014.

[9] J. Harmer, "The practice of English language teaching. Harlow," Engl. Pearson Educ., 2007.

[10] I. Mustapha, N. T. Van, M. Shahverdi, M. I. Qureshi, and N. Khan, "Effectiveness of Digital Technology in Education During COVID-19 Pandemic. A Bibliometric Analysis.," Int. J. Interact. Mob. Technol., vol. 15, no. 8, 2021. https://doi.org/10.3991/ijim.v15i08. $\underline{20415}$

[11] S. Khatoony and M. Nezhadmehr, "EFL teachers' challenges in integration of technology for online classrooms during Coronavirus (COVID-19) pandemic in Iran," AJELP Asian J. English Lang. Pedagog., vol. 8, no. 2, pp. 89-104, 2020. https://doi.org/10.37134/ ajelp.vol8.2.7.2020

[12] S. Kumar and M. Tammelin, "Integrating ICT into language learning and teaching," Johannes KeplerUniversität Linz, 2008. https://www.academia.edu/235896/

[13] M.-N. Bessagnet, L. Schlenker, and R. Aiken, "Using E-collaboration to improve management education: Three Scenarios," JISTEM-Journal Inf. Syst. Technol. Manag., vol. 2, no. 1, pp. 81-94, 2005. https://doi.org/10.1590/S1807-17752005000100007

[14] Z.-Y. Liu, N. Lomovtseva, and E. Korobeynikova, "Online learning platforms: Reconstructing modern higher education," Int. J. Emerg. Technol. Learn., vol. 15, no. 13, pp. 4-21, 2020. https://doi.org/10.3991/ijet.v15i13.14645

[15] K. Gertrude and others, "Maximizing the effects of collaborative learning through ICT," Procedia-Social Behav. Sci., vol. 176, pp. 1005-1011, 2015. https://doi.org/10. 1016/j.sbspro.2015.01.571

[16] U. Stickler, "Chatting, chatten or chattare: Using a multilingual workspace for language and culture learning," Int. J. Emerg. Technol. Learn., vol. 3, no. 2008, 2008. https://doi.org/10.3991/ijet.v3i1.731

[17] N. G. Fernández, M. L. R. Moreno, and J. R. Guerra, "Brecha digital en tiempo del COVID-19," Hekademos Rev. Educ. Digit., no. 28, pp. 76-85, 2020.

[18] M. Kanno, "Maintaining and Enhancing Students' Collaborative Learning in a Japanese EFL Higher Education Context," Commun. is RObust when NAtions Come Together Importance, 2020. https://doi.org/10.34097/jeicom_SP_june2020_4

[19] C. K. S. Singh et al., "Rethinking English language teaching through Telegram, Whatsapp, Google classroom and Zoom," Syst. Rev. Pharm., vol. 11, no. 11, pp. 45-54, 2020.

[20] R. A. Maulidya, N. F. Atasyah, N. Husna, D. N. Hidayat, and F. Hamid, "The Implementation of Communicative Media for Teaching English as a Foreign Language (EFL) during Pandemic of Covid-19 in Indonesian Senior High Schools," Fakt. J. Ilm. Kependidikan, vol. 8, no. 1, pp. 73-92, 2021.

[21] C. Hodges, S. Moore, B. Lockee, T. Trust, A. Bond, and others, "The difference between emergency remote teaching and online learning," Educ. Rev., vol. 27, no. 1, pp. 1-9, 2020.

[22] A. Bozkurt and R. C. Sharma, "Emergency remote teaching in a time of global crisis due to CoronaVirus pandemic," Asian J. Distance Educ., vol. 15, no. 1, pp. i--vi, 2020. https://doi.org/10.5281/zenodo.3778083 
[23] L. S. Schlesselman, "Perspective from a teaching and learning center during emergency remote teaching," Am. J. Pharm. Educ., vol. 84, no. 8, 2020.

[24] N. Tarihoran, M. Farkhan, and H. HUNAINAH, "Mentoring EFL Teaching During the Covid-19 Pandemic," ^.I\}lkö^u\{g\}\}retim Online (IOO)-Elementary Educ. Online, vol. 20, no. 1, pp. 717-726, 2021. https://doi.org/10.17051/ilkonline.2021.01.62

[25] J. E. Dyment and J. Downing, "Online initial teacher education students' perceptions of using web conferences to support professional conversations," Aust. J. Teach. Educ., vol. 43, no. 4, pp. 68-91, 2018. https://doi.org/10.14221/ajte.2018v43n4.5

[26] J. Delahunty, “'Who am I?': Exploring identity in online discussion forums,” Int. J. Educ. Res., vol. 53, pp. 407-420, 2012. https://doi.org/10.1016/j.ijer.2012.05.005

[27] P. Sepulveda-Escobar and A. Morrison, "Online teaching placement during the COVID-19 pandemic in Chile: challenges and opportunities," Eur. J. Teach. Educ., vol. 43, no. 4, pp. 587-607, 2020. https://doi.org/10.1080/02619768.2020.1820981

[28] A. Garcia-Valcárcel-Muñoz-Repiso, V. Basilotta-Gómez-Pablos, and C. López-Garcia, "ICT in collaborative learning in the classroom of elementary and secondary education," Comunicar, vol. 21, no. 42, pp. 65-74, 2014. https://doi.org/10.3916/c42-2014-06

[29] Q. Wang, "Using online shared workspaces to support group collaborative learning," Comput. Educ., vol. 55, no. 3, pp. 1270-1276, 2010. https://doi.org/10.1016/ j.compedu.2010.05.023

[30] Y. X. D. Pinzón and others, "Diversidades, adversidades y oportunidades de la alfabetización digital,” Exp. Investig. y Significativas, vol. 6, no. 6, p. 18, 2020.

[31] Y.-C. Kuo, H.-C. Chu, and C.-H. Huang, "A learning style-based grouping collaborative learning approach to improve EFL students' performance in English courses," J. Educ. Technol. Soc., vol. 18, no. 2, pp. 284-298, 2015.

[32] G. E. C. Parra, "Inclusion de estudiantes de lenguas extranjeras en procesos colaborativos de aprendizaje mediados por la web 2.0," Rev. PROFILE, vol. 17, no. 2, pp. 137-147, 2015. http://dx.doi.org/10.15446/profile.v17n2.47510

[33] E. Shalevska, "The unforeseen advantages of remote ESL/EFL classes," Eur. J. English Lang. Teach., vol. 6, no. 3, 2021. http://dx.doi.org/10.46827/ejel.v6i3.3557

[34] D. Little, "Common European Framework of Reference for Languages," TESOL Encycl. English Lang. Teach., pp. 1-7, 2018.

[35] J. W. Creswell and J. D. Creswell, Research design: Qualitative, quantitative, and mixed methods approaches. Sage publications, 2017.

[36] M. A. I. Le Thi, "Benefits and challenges to integrate ICT in EFL teaching and learning activities," J. Res. Method Educ., vol. 10, no. 3, pp. 46-50, 2020.

[37] S. P. M. Ibna and H. Habil, "A Systematic Overview of Issues for Developing EFL Learners' Oral English Communication Skills," J. Lang. Educ., vol. 7, no. 1, pp. 229-240, 2021. https://doi.org/10.17323/jle.2021.10737

[38] M. B. Telleria and others, "Las TIC en la educación: nuevos ambientes de aprendizaje para la interacción educativa," Rev. Teor $\backslash$ \i\}a y Didáctica las Ciencias Soc., no. 18, pp. 83112, 2012. https://doi.org/10.1016/s0187-893x(18)30104-6

[39] W.-C. Lin and S. C. Yang, "Exploring the Roles of Google. doc and Peer e-Tutors in English Writing.," English Teach. Pract. Crit., vol. 12, no. 1, pp. 79-90, 2013.

[40] N. Gulati and P. Bhatt, "Google Apps for English Language Teaching and Learning: The Classroom and Beyond," Achievers J. J. English Lang. Lit. Cult., vol. 6, no. 4, pp. 29-44, 2021.

[41] M. F. Blasco López and N. Recuero Virto, "Technological acceptance of Google Drive as E-learning Tool," in 2020 The 4th International Conference on Digital Technology in Education, 2020, pp. 1-4. https://doi.org/10.1145/3429630.3429636 
Paper-Virtual Workspaces for Enhancing Collaborative Work in EFL Learning: A Case Study in...

[42] D. H. Tri and N. H. T. Nguyen, "An exploratory study of ICT use in English language learning among EFL university students," Teach. English with Technol., vol. 14, no. 4, pp. 32-46, 2014.

\section{Authors}

Luz Castillo-Cuesta is a Master of Science in Teaching English as a Foreign Language at Nova Southeastern University of Florida, U.S.A. Master of Teaching English as a Foreign Language at Universidad Técnica Particular de Loja (UTPL), Ecuador. Undergraduate studies in Education: EFL teaching, Professor for fourteen years at UTPL, former coordinator of the English Major and the Academic Board of the English Major. Member of the Research Group EFL Learning, Teaching and Technology, and the EFL Teachers' Network in Ecuador. Linguistics Doctoral student at Universidad Nacional del Rosario, Argentina. Co-author of different indexed articles and four book chapters.

Cesar Ochoa-Cueva holds a Master's Degree in Teaching English as a ForeignLanguage at NOVA Southeastern University of Florida U.S.A. He currently works for Universidad Técnica Particular de Loja (UTPL) in Ecuador. He has worked as an EFL teacher for about 18 years. He has been the Head of the Research and Services English Center at UTPL and he has been co-author of different manuscripts in indexed journals (Email: caochoa@utpl.edu.ec).

Paola Cabrera-Solano is a Master in Distance Education and a Master in Teaching English as a Foreign Language from Universidad Técnica Particular de Loja and Nova Southeastern University of the United States. With undergraduate studies in Teaching English as a Foreign Language and Business Administration. Language and Linguistics Doctoral student at Universidad Nacional de Rosario, Argentina. Former administrative coordinator of the Master's Degree in TEFL, and Former Head of the English Language Teaching Unit. Research professor in the Contemporary Languages Section of the Department of Education at UTPL, and member of the Research Group “EFL Learning, Teaching and Technology” (Email: pacabrera@utpl.edu.ec).

Article submitted 2021-08-02. Resubmitted 2021-10-19. Final acceptance 2021-10-19. Final version published as submitted by the authors. 